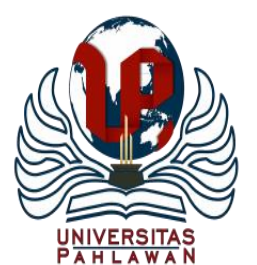

Jurnal Basicedu Volume 5 Nomor 1 Tahun 2021 Halaman 317-326

JURNAL BASICEDU

Research \& Learning in Elementary Education

https://jbasic.org/index.php/basicedu

\title{
Apresiasi Cerita Rakyat sebagai Upaya Memperkuat Karakter Siswa dalam Menghadapi Revolusi Industri 4.0
}

\author{
Kuswara $^{1}$, Yena Sumayana ${ }^{2}$ \\ STKIP Sebelas April Sumedang, Jawa Barat, Indonesia ${ }^{1,2}$ \\ E-mail: sumayana0602@gmail.com ${ }^{1} \underline{\text { kuswararachman@gmail.com }}^{2}$
}

\begin{abstract}
Abstrak
Kemajuan dunia teknologi sudah memasuki era revolusi industri 4.0. Revolusi industri 4.0 merupakan optimalisasi kemajuan teknologi dengan mengubah cara kerja manusia menjadi digitalisasi. Revolusi industri tentu saja harus diimbangi dengan revolusi mental guna mempersiapkan para pengguna yang berkarakter dan berkemajuan. Di sekolah, guru harus memberikan penguatan-penguatan kepada siswa tentang dampak revolusi industri 4.0 agar karakter mereka tidak luntur serta mempunyai visi untuk maju. Cerita rakyat merupakan tradisi lisan yang diwariskan oleh para leluhur secara turun temurun dari satu generasi ke generasi berikutnya. Dalam cerita rakyat banyak memuat tentang sejarah, adat istiadat, pandangan hidup, politik, kepemimpinan, dan cita-cita (keinginan). Cerita rakyat berfungsi sebagai media pendidikan dan sarana hiburan guna menumbuhkan kecerdasan emosional dan sosial siswa serta dapat dijadikan sarana untuk memperkuat karakter siswa. Tujuan penulisan makalah ini untuk menguraikan kebermanfaatan apresiasi cerita rakyat bagi penguatan karakter siswa. Hal tersebut dimaksudkan bahwa kenyataan dilapangan saat ini apresiasi masyarakat khususnya siswa terhadap cerita rakyat mengalami penurunan karena tergeser oleh cerita-cerita modern. Adapun metode penelitian yang digunakan adalah kualitatif deskriftif.
\end{abstract}

Kata kunci: apresiasi cerita rakyat,karakter siswa, revolusi industri 4.0

\begin{abstract}
Progression of technological world has already reached age of the industrial revolution 4.0. This industrial revolution is optimization of the technological development by converting the human work procedure to be in digital codes. It should be balance with the mental revolution in order to prepare users with high-character and committed. Teachers, at schools, need to provide strengthening to the students around impact of the industrial revolution 4.0 in order that their good character is increasingly strong and possesses a vision to be better. The folktale is oral tradition inherited by the ancient conventionally from a generation to another one. In this case, a folktale contains about history, tradition, way of life, politics, leadership, and ambition. It also functions as a means of education as well as recreation to arouse both emotional and social intelligence of the students and can be a medium of reinforcing their characters. The objective of writing this paper is to explain usefulness of the folktales appreciation for the strengthening of students' character. It means that in fact it is rare that the students appreciate them since they are influenced by the modern tales. The method used in this research is descriptive qualitative.
\end{abstract}

Keywords: folktale appreciation, students' character, industrial revolution 4.0

Copyright (c) 2021 Kuswara, Yena Sumayana

$\triangle$ Corresponding author

Address : Jl. Raya Cinunuk No. 115 Bandung

ISSN 2580-3735 (Media Cetak)

Email : sumayana0602@gmail.com

ISSN 2580-1147 (Media Online)

DOI: https://doi.org/10.31004/basicedu.v5i1.678 


\section{PENDAHULUAN}

Saat ini dunia sedang memasuki abad generasi keempat dalam era revolusi industri dalam berbagai sektor kehidupan. Hal tersebut ditandai dengan era digitalisasi yang terjadi dalam berbagai bidang dan kebutuhan manusia. Khususnya di Indonesia dampak tersebut sangat terasa dengan beralihnya kebiasaan masyarakat yang ketergantungan terhadap gadget dan transaksi jual beli berbasis online. Para pakar atau ahli menyebut era ini sebagai era revolusi industri 4.0. Era digitalisasi tersebut sangat berdampak pula terhadap laju pergerakan perekonomian yang sebagain besar mengalami pergeseran dari manual ke otomatisasi mekanis. Hal tersebut menunjukan bahwa pergerakan yang semula bersifat sentral pada manusia, sekarang sudah bergeser kepada digitalisasi teknologi. Berdasarkan hasil penelitian (Razdan et al., 2013) diperoleh hasil bahwa dampak dari digital technology menuju Revolusi Industri 4.0 dalam lima (5) tahun kedepan akan ada 52,6 juta jenis pekerjaan mengalami pergeseran atau hilang dari muka bumi. Hasil penelitian tersebut memberikan gambaran bahwa sesorang yang mempunyai pola pikir untuk bereksistensi serta berkompetisi secara global harus mempersiapkan diri baik mental maupun keahlian (skill).

Faktor utama dalam mempersiapkan mental dan skill tentu saja seseorang harus mempunyai kepribadian baik (good personality), perilaku yang baik (behavioral attitude), menaikan kompetensi diri dan menjadi kaum literat (Suwardana, 2018). Persiapan diri dapat dilaksanakan melalui jalur pendidikan di sekolah. Proses pendidikan di sekolah dapat diimplementasikan melalui kegiatan pembelajaran salah satunya pada pembelajaran Bahasa Indonesia.

Pembelajaran bahasa Indonesia di sekolah menyangkut aspek kebahasaan dan kesusastraan. Salah satu aspek dari kesusastraan yang tertuang dalam kompetensi dasar adalah apresiasi cerita rakyat. Pembelajaran sastra di sekolah tentu saja memiliki manfaat yang besar bagi siswa yakni dapat meningkatkan kemampuan serta kematangan intelektual dan kecerdasan emosional siswa. Selain itu, pembelajaran sastra di sekolah dapat menumbuhkan kreativitas siswa untuk terus berkarya. Pembelajaran apresiasi cerita rakyat memiliki berbagai manfaat di antaranya (1) dapat meningkatkan rasa kecintaan seseorang terhadap budaya daerah (folklore) sebagai budaya nusantara, (2) dapat meningkatkan rasa kecintaan seseorang terhadap apresiasi sastra, dan (3) dapat digunakan untuk mendidik anak (siswa) dengan mengajarkan dan menanamkan beragam nilai-nilai moral (budi pekerti). Dengan pembelajaran apresiasi seseorang dapat menganalisis karakterkarakter dari setiap tokoh yang termuat dalam cerita tersebut. Tokoh-tokoh yang termuat atau berperan dalam cerita tersebut dapat memberikan teladan bagi seseorang sesuai dengan karakter serta sifat yang diperankannya.

Persoalan budaya dan karakter bangsa memang menjadi sorotan tajam masyarakat sehingga seringkali menjadi bahan perdebatan dan dialog diberbagai kesempatan. Para ahli, pengamat sosial, maupun pengamat pendidikan seringkali membicarakan mengenai persoalan budaya dan karakter bangsa di berbagai forum dan seminar 
baik tingkat lokal, nasional, maupun internasional (Atmaja et al., 2020). Berbagai alternatif penyelesaian masalah budaya dan karakter bangsa diajukan beragam oleh beberapa kalangan. Imbasnya lembaga pendidikan (sekolah) dipilih menjadi salah satu alternatif yang bersifat preventif untuk menyelesaikan masalah tersebut (Dewantara et al., 2020).

Apabila kita analisis secara mendalam, karakter serta sifat anak (siswa) cenderung pada keinginan untuk meniru dan mengidentikan dirinya dengan tokoh yang dikaguminya. Melalui cerita rakyat siswa akan lebih mudah dalam menganalisis karakter-karakter pada masingmasing setiap tokoh yang ditampilkan melalui peran masing-masing dalam cerita. Dalam proses pembelajaran bahasa dan sastra Indonesia guru perlu mengupayakan strategi yang sesuai dengan tujuan yang diharapkan. Khususnya dalam pembelajaran sastra strategi yang mesti diterapkan guru adalah strategi yang bermanfaat bagi kehidupan siswa di masa mendatang dan sesuai dengan kebutuhan serta tantangan global sehingga mereka siap menghadapinya.

Hal tepenting yang perlu dilakukan adalah penguatan karakter siswa. Penguatan pendidikan karakter menjadi perhatian utama di era revolusi industri, dimana dunia anak mulai dipengaruhi oleh tekhnologi yang juga membawa dampak negatif bagi anak jika kontrol guru dan orang tua lepas kendali. Penguatan Pendidikan karakter adalah Gerakan Pendidikan di sekolah untuk memperkuat karakter siswa melalui harmonisasi olah hati (etik), olah rasa (estetik), olah pikir (literasi), dan olah raga (kinestetik) (La ode Onde et al., 2020).

Era revolusi industry 4.0 menuntut semua elemen masyarakat untuk mempersiapkan diri dan menjadi bagian di dalamnya. Penguatan karakter bangsa perlu dilakukan agar mereka menjadi bangsa yang kuat dan berkualitas serta mampu berdaya saing global. Hal tersebut dapat dilakukan dengan mengapresiasi cerita rakyat sebagai sarana memperkuat karakter siswa sebagai generasi penerus bangsa. Sealin itu, cerita rakyat dapat dijadikan sebagai identitas pemersatu bangsa sehingga bangsa kita menjadi makmur, sejahtera, dan bermartabat.

\section{METODE}

Sesuai dengan permasalahan yang telah diungkapkan di atas, maka metode yang digunakan dalam penulisan artikel ini adalah kualitatif deskriptif. Karena tujuan penelitian ini adalah untuk mendeskripsikan nilai-nilai yang terkandung dalam apresiasi cerita rakyat. Disamping itu, karena fenomena yang menjadi sasaran penelitian dideskripsikan sebagaimana adanya tanpa disertai dengan perhitungan statistik, maka metode penelitian ini menggunakan metode kualitatif (Rianse \& Abdi, 2008). Selain itu, kajian atau telaahan terhadap hasil penelitian dan teori-teori yang relevan dengan artikel dijadikan cara oleh penulis untuk menjawab tujuan penulisan artikel ini. 
320 Apresiasi Cerita Rakyat Sebagai Upaya Memperkuat Karakter Siswa Dalam Menghadapi Revolusi Industri 4.0 - Kuswara, Yena Sumayana

DOI: https://doi.org/10.31004/basicedu.v5i1.678

\section{HASIL DAN PEMBAHASAN}

\section{Konsep Revolusi Industri 4.0}

Dunia pada umumnya, dan Indonesia pada khususnya, sedang memasuki era industri baru yang ditandai dengan era digitalisasi di berbagai sektor kehidupan. Para pakar menyebut ini sebagai era revolusi industri 4.0 (Cho, S. D., dalam (Suwardana, 2018). Inovasi adalah faktor paling penting yang menentukan daya saing suatu negara dalam berbagai sektor. Hasil capaian inovasi kedepan ditentukan sejauh mana dapat merumuskan body of knowledge terkait manajemen inovasi, technology transfer and business incubation, science and Technopark. Istilah "Revolusi Industri" diperkenalkan oleh Friedrich Engels dan Louis-Auguste Blanqui di pertengahan abad ke-19. Revolusi industri ini pun sedang berjalan dari masa ke masa. Sedangkan istilah "Industri 4.0" lahir dari ide revolusi industri keempat. Perubahan fase ke fase memberi perbedaan artikulatif pada sisi kegunaaannya. Fase pertama (1.0) bertempuh pada penemuan mesin yang menitikberatkan (stressing) pada mekanisasi produksi. Fase kedua (2.0) sudah beranjak pada etape produksi massal yang terintegrasi dengan quality control dan standarisasi. Fase ketiga (3.0) memasuki tahapan keseragaman secara massal yang bertumpu pada integrasi komputerisasi. Fase keempat (4.0) telah menghadirkan digitalisasi dan otomatisasi perpaduan internet dengan manufaktur (Suwardana, 2018).

Lebih lanjut (Suwardana, 2018) mengungkapkan bahwa dasar perubahan ini sebenarnya adalah pemenuhan hasrat keinginan akan pemenuhan kebutuhan manusia secara cepat dan berkualitas. Revolusi Industri telah mengubah cara kerja manusia dari penggunaan manual menjadi otomatisasi atau digitalisasi. Inovasi menjadi kunci eksistensi dari perubahan itu sendiri. Pada konteks revolusi industri dapat diterjemahkan proses yang terjadi sebenarnya adalah perubahan sosial dan kebudayaan yang berlangsung secara cepat dan menyangkut dasar kebutuhan pokok (needs) dengan keinginan (wants) masyarakat. Perjalanan perubahan dalam revolusi yang terjadi dapat direncanakan atau tanpa direncanakan terlebih dahulu dan dapat dijalankan tanpa kekerasan atau melalui kekerasan.

Industri 4.0 tentu saja memberikan manfaat yang cukup besar bagi kehidupan manusia, tetapi tantangannya juga sangat besar sehingga memerlukan kecermatan dalam menghadapinya. (Prasetyo \& Sutopo, 2018) berpendapat bahwa tantangan yang dihadapi oleh suatu negara ketika menerapkan Industri 4.0 adalah munculnya resistansi terhadap perubahan demografi dan aspek sosial, ketidakstabilan kondisi politik, keterbatasan sumber daya, risiko bencana alam, dan tuntutan penerapan teknologi yang ramah lingkungan. Selanjutnya, (Qin et al., 2016) terdapat kesenjangan yang cukup lebar dari sisi teknologi antara kondisi dunia industri saat ini dengan kondisi yang diharapkan dari Industri 4.0. Penelitian yang dilakukan oleh (Balasingham, 2016) juga menunjukkan adanya faktor keengganan perusahaan dalam menerapkan Industri 4.0 karena khawatir terhadap ketidakpastian manfaatnya. Dengan demikian, tantangan besar dalam menghadapi era industri 4.0 akan terjadi pada lima aspek penting, yakni 
pengetahuan, teknologi, ekonomi, sosial budaya, dan politik. Dalam menjawab tantangan tersebut tentu saja bangsa Indonesia harus mempersiapkan diri serta menyusun rencana strategis baik dalam tataran individu, pemerintah, para akademisi, maupun praktisi.

Keniscayaan ini mengharuskan adanya strategi kependidikan melalui pranata yang dikandungnya mampu mengakomodasi perubahanperubahan peradaban global. Arah perubahan ini mengacu kepada hal-hal yang bersifat imperatif maupun empirik. Menurut pakar pendidikan, secara imperatif berarti pranata sosial pendidikan dan pelatihan (diklat), khususnya sekolah dan perguruan tinggi, tidak hanya bertugas memelihara dan meneruskan tradisi yang berlaku di masyarakat (Fadjar, 2005).

\section{Konsep Apresiasi Cerita Rakyat}

Apresiasi berasal dari bahasa Inggris yaitu apreciation yang bermakna "mengindahkan" atau "menghargai". Proses mengindahkan atau menghargai tersebut berupa pertimbangan terhadap karya sastra dalam bentuk penilaian terhadap isi cerita, pemahaman terhadap makna yang disampaikan dalam cerita, dan pengenalan karakter tokoh yang sesuai dengan apa yang digambarkan serta pemahaman terhadap pesan yang disampaikan. (Aminudddin \& Suryana, 2000) mengemukakan bahwa apresiasi dapat dimaknai sebagai pengenalan karakter tokoh melalui perasaan atau kepekaan batin seseorang serta memahami atas nilai-nilai keindahan melalui peristiwa yang diungkapkan oleh pengarang dalam sebuah karya sastra.
Kegiatan mengapresiasi karya sastra sebagai suatu upaya ketika proses mengapresiasi melibatkan tiga unsur yaitu: (1) aspek kognitif, dimana aspek tersebut berhubungan dengan keterkaitannya dengan intelektual para pembaca ketika proses memahami unsur-unsur karya sastra yang sifatnya obyektif (unsur intrinsik dan ekstrinsik); (2) aspek emotif, berhubungan dengan keterkaitannya dengan emosi jiwa para pembaca ketika membaca dan menghayati unsur keindahan dalam sebuah karya sastra yang sudah dibaca; dan (3) aspek evaluatif sangat berhubungan langsung ketika sedang memberikan penilaian terhadap karya sastra mengenai baik buruknya karya sastra, indah tidaknya karya sastra, sesuai atau tidaknya karya sastra, yang dilakukan secara personal sesuai dengan kriteria penilaian masing-masing (Aminudddin \& Suryana, 2000).

Bentuk dari karya sastra salah satunya adalah cerita rakyat. Cerita rakyat merupakan cerita zaman dahulu yang hidup dikalangan rakyat dan diwariskan serta dituturkan secara lisan. Selanjutnya (Wahyuddin, 2016) menyatakan bahwa cerita rakyat merupakan warisan budaya nasional dan masih mempunyai nilai-nilai yang patut dikembangkan dan dimanfaatkan untuk kehidupan masa kini dan masa yang akan datang antara lain hubungannya dengan apresiasi sastra. Cerita rakyat juga telah lama lahir sebagai wahana pemahaman dan gagasan serta pewaris tata nilai yang tumbuh dalam masyarakat. Bahkan cerita rakyat telah berabad-abad berperan sebagai dasar komunikasi antara pencipta dan masyarakat dalam arti ciptaan yang berdasarkan lisan dan lebih 
mudah diganti karena ada unsur yang dikenal masyarakat.

Cerita rakyat terdiri dari beberapa jenis. (Sedyawati, 1981) membagi cerita rakyat dalam tiga jenis, yaitu (1) mite, merupakan cerita rakyat yang berbentuk prosa yang oleh pewarisnya dipercaya sebagian kejadian yang benar-benar terjadi pada zaman dahulu yang bisa berwujud dogma yang dianggap suci seperti dewa, pahlawan kebudayaan, dan binatang kepercayaan yang dianggap keramat, (2) legenda, merupakan cerita rakyat yang sama halnya seperti mite akan tetapi perkembangan legenda kejadiaannya jauh lebih muda dibandindingkan mite. Legenda bersifat sekuler atau suci dan tokoh utamanya adalah manusia. Dalam cerita rakyat (folklore) bercerita tentang migrasi, peperangan, raja-raja, dan kedinastian dalam kerajaan, (3) dongeng, merupakan cerita rakyat dalam bentuk prosa yang dianggap sebagai cerita rekaan belaka. Dalam dongeng perihal kebenaran tidaklah jadi permasalahan karena dongeng dianggap sebagai hiburan. Akan tetapi, meskipun dongeng identik sebagai sarana hiburan, dongen pula oleh para pengarangnya disisipkan pesan-pesan yang mengandung unsur nasihat atau pesan moral tentang kehidupan.

Sebuah karya sastra tentu saja memiliki dua unsur yang membangun. Cerita rakyatpun memiliki dua unsur yang membangun, yakni unsur intrinsik dan ekstrinsik. Unsur intrinsik merupakan unsur penting yang terdapat di dalam cerita, yang membangun struktur sebuah karya sastra. Sementara itu unsur ekstrinsik merupakan unsur yang membangun struktur sebuah karya sastra dari luar isi cerita (Burhan, 2005). Unsur intrinsik akan diuraikan sebagai berikut:

a. Tema. Tema merupakan pokok inti yang terdapat di dalam isi cerita.

b. Majas (gaya bahasa). Gaya bahasa merupakan bahasa kiasan yang digunakan pengarang melalui dialog-dialog dalam cerita.

c. Latar (setting). Latar/setting dalam cerita terdapat tiga jenis yaitu latar tempat, latar waktu, dan latar belakang suasana.

d. Tokoh. Tokoh adalah pelaku dalam sebuah karyas sastra. Sifat/karakter tokoh dibagi menjadi tiga, yaitu: karakter tokoh utama (protagonis), karakter lawan yang menonjol (antagonis), dan tokoh pendamping (tritagonis).

e. Alur (jalan cerita). Alur (jalan cerita) adalah sebuah urutan peristiwa yang terjadi dalam cerita. Jalan cerita dalam karya sastra terdapat lima rangkaian cerita, yakni: pembukaan, pengembangan, konflik, rekonsiliasi, dan penyelesaian. Alur dalam sebuah karya sastra terbagi atas tiga jenis yakni alur maju, mundur, dan campuran.

f. Sudut pandang (point of view). Sudut pandang (point of view) merupakan unsur instrinsik yang menempatkan posisi penulis (dirinya) di dalam cerita. Sudut pandang dalam karya sastra terbagi menjadi dua, yakni sudut pandang sebagai orang pertama dan sudut pandang sebagai orang ketiga.

g. Amanat atau pesan moral. Amanat adalah nilainilai yang terdapat dalam cerita dongeng yang ingin disampaikan penulis kepada pembaca. 
Sementara itu, unsur ekstrinsik yang terdapat dalam karya sastra dongeng adalah unsur yang terdapat pada diri seorang penulis itu sendiri. Antara lain, latar belakang penulis, kehidupan ekonimi penulis, agama penulis, pendidikan penulis, kondisi sosial masyarakat, dan hukum.

\section{Konsep Karakter Siswa}

Karakter adalah watak, tabiat, akhlak atau kepribadian seseorang yang terbentuk dari hasil internalisasi kebajikan (virtues) yang diyakini dan digunakan sebagai landasan untuk cara pandang, berpikir, bersikap dan bertindak (Depdiknas \& No, 2003). Perwujudan karakter dapat dilihat ketika seseorang bersikap atau berperilaku dalam lingkungan sosialnya. Sikap dan perilaku tersebut merupakan wujud keinginan baik untuk melakukan suatu tindakan berkaitan dengan intelektualitas seseorang, moralitas, emosional, dan komitmen seseorang dalam berinteraksi dengan masyarakat (Naim, 2012). Hal tersebut sejalan pula dengan pendapat (Abad, n.d.) bahwa karakter merupakan serangkaian wujud sikap (attitudes), perilaku (behaviors), motivasi (motivations), dan keterampilan (skills) seseorang yang digunakan sebagai landasan dalam berpikir, menentukan cara pandang, bekerjasama, dan bertindak sehingga dapat berguna serta bermanfaat dalam mebangun keutuhan di lingkungan keluarga dan masyarakat.

Karakter dapat pula dikatakan sebagai ciri khas seseorang atau individu. Siswa merupakan individu yang sedang menempuh pendidikan di sekolah dan tentu saja memiliki karakter yang berbeda-beda. Oleh karena itu, dalam diri siswa perlu ditanamkan nilai-nilai karakter yang baik. Dalam proses penanaman nilai-nilai karakter kepada siswa dapat dilakukan melalui proses pembelajaran dengan didasari oleh kemauan, kesadaran, serta tindakan untuk melaksanakan nilai-nilai tersebut salah satunya melalui apresiasi cerita rakyat sehingga menjadi sebuah pembiasaan. Nilai-nilai dalam apresiasi cerita rakyat tersebut dapat dijadikan sebagai sarana pengembangan kepribadian guna memperkuat karakter siswa dalam menghadapi revolusi industri 4.0.

\section{Apresiasi Cerita Rakyat Sebagai Upaya Memperkuat Karakter Siswa dalam Menghadapi Revolusi Industri 4.0}

Dalam penguatan karakter siswa tentu saja ada tujuan yang ingin dicapai. Adapun tujuan penguatan pendidikan karakter menurut (Salahudin \& Alkrienciehie, 2013) antara lain: (1) menanamkan jiwa kepemimpinan dan tanggung jawab; (2) mengembangkan siswa agar menjadi manusia yang mandiri, kreatif, dan berwawasan kebangsaan; dan (3) mengembangkan lingkungan kehidupan sekolah sebagai lingkungan belajar yang aman, jujur, dan penuh kreativitas.

Di sekolah, kurikulum mata pelajaran Bahasa Indonesia pada setiap jenjang mempunyai dua kompetensi yang harus dicapai, yaitu kompetensi dalam aspek kebahasaan dan kompetensi dalam aspek kesastraan. Salah satu aspek kemampuan kesastraan yang mesti dicapai siswa adalah apresiasi cerita rakyat yang disampaikan kepada siswa baik secara lisan maupun tulisan dengan tujuan menentukan hal-hal yang menarik dari cerita rakyat tersebut serta 
siswa mampu menunjukkan relevansi isi cerita rakyat tersebut dengan situasi dalam kehidupan sekarang. Dalam proses pembelajaran apresiasi yang pertama perlu dilakukan adalah siswa harus mampu memahami isi cerita dengan baik, kemudian siswa mampu menganalisis cerita tersebut. Proses tersebut harus dilakukan siswa secara terus menerus tentu saja dengan latihan dan bimbingan guru. Tujuannya agar siswa termotivasi ketika proses pembelajaran apresiasi cerita rakyat berlangsung. Oleh karena itu, dalam kegitatan pembelajaran mengapresiasi cerita rakyat guru hendaknya menyampaikan teori berbasis praktik, sehingga siswa dalam pembelajaran sastra khususnya apresiasi cerita rakyat dapat mencapai tujuan dengan baik sesuai dengan yang diharapkan.

Dalam (Nasional, 2003) tentang Sistem Pendidikan Nasional Bab I Pasal I Ayat I dikatakan, bahwa "pendidikan adalah usaha sadar dan terencana untuk mewujudkan suasana belajar dan proses pembelajaran peserta didik secara aktif mengembangkan potensi dirinya untuk memiliki kekuatan spiritual keagamaan, pengendalian diri, kepribadian, kecerdasan, akhlak mulia, serta keterampilan yang diperlukan dirinya, masyarakat, bangsa, dan Negara". Apabila kita kaitkan dengan pembelajaran sasrta, terungkap bahwa dalam proses pembelajaran sastra bagian dari proses penanaman nilai-nilai karakter, oleh sebab itu siswa secara aktif harus mampu mengembangkan potensinya agar memiliki kekuatan spiritual keagamaan, pengendalian diri, kepribadian, kecerdasan, akhlak mulia, dan kemandirian.
Negara Indonesia adalah negara yang luas dan memiliki keanekaragaman budaya, bahasa, adat istiadat, suku bangsa, dan agama. Jumlah penduduk Indonesia menempati posisi keempat dunia. Jumlah penduduk yang besar tentu saja harus diimbangi dengan produktivitas guna mengahadapi perkembangan dunia yang semakin maju. Kualitas penduduk Indonesia relatif rendah dibandingkan dengan penduduk negara-negara tetangga. Hal tersebut dapat dilihat dari penyerapan perusahaan terhadap tenaga kerja lokal masih kalah oleh tenaga kerja asing. Dalam dunia teknologi bangsa Indonesia lebih suka bertindak sebagai pengguna daripada sebagai pencipta karena bangsa Indonesia masih menganut budaya instan. Indonesia bisa melakukan lompatan sebagai penonton menjadi pemain dalam revolusi industri manakala pembangunan manusia dilakukan melalui penguatan pendidikan karakter sebagai bagian dari revolusi mental yang diprogramkan Presiden Jokowi. Penguatan karakter dapat dilakukan melalui proses pendidikan di sekolah terhadap siswa sebagai generasi penerus bangsa.

Negara Indonesia harus banyak belajar dari negara-negara maju, dimana mereka kekuatan terbesarnya terletak pada bangsanya itu sendiri. Di negara-negara maju langkah prioritas pemerintah adalah menguatkan karakter bangsanya. Mereka berpandangan bahwa dengan memajukan pendidikan karakter bangsa, maka bangsa tersebut akan maju pula dalam ilmu pengetahuannya, budaya dan teknologi. Era industi sudah bergeser seiring kebutuhan dan meningkatnya persaingan dunia teknologi. Industri 4.0 mengisyaratkan bahwa segala kebutuhan manusia terkait dengan 
kehidupannya sangat bergantung pada proses digitalisasi. Apabila manusia sudah menguasai hal itu maka mereka akan merasakan betapa mudahnya menjalani kehidupan sekarang ini. Kunci keberhasilan memasuki revolusi industri 4.0 adalah memperkuat karakter bangsa dimulai sejak dini dari usia pra-sekolah, sekolah, sampai perguruan tinggi. Penguatan karakter yang merupakan bagian dari revolusi mental menyadarkan kita betapa pentingnya meningkatkan kompetensi diri melalui proses pembelajaran guna meningkatkan potensi diri.

Pendidikan yang dilaksanakan di sekolah dilakukan guru melalui proses pembelajaran. Proses pembelajaran yang mempelajari berbagai disiplin ilmu tentu saja dapat mengantarkan bangsa Indonesia makmur dan sejahtera. Sintesa dari revolusi industri 4.0 dan penguatan karakter siswa bahwa revolusi industri 4.0 akan melahirkan bangsa Indonesia yang sejahtera dalam bidang ekonomi dan pembangunan, sedangkan penguatan karakter tentu saja sebagai cara membentengi serta mempersiapkan bangsa Indonesia agar memiliki karakter yang baik serta memiliki mental yang kuat guna menjadi manusia yang berkualitas dan unggul. Karya sastra berupa cerita rakyat menjadi saran untuk memperkuat karakter siswa. Peran penting apresiasi cerita rakyat terhadap perkembangan karakter seseorang merupakan bukti nyata bahwa cerita rakyat mengandung nilainilai kehidupan sebagai salah satu bagian dalam pendidikan karakter siswa untuk mengantisipasi generasi digital (otomatisasi) dan kesadaran dalam merespon kehidupan global.

\section{SIMPULAN}

Penguatan karakter siswa dimulai pada saat proses pembelajaran berlangsung. Pembelajaran sastra dapat dioptimalkan sebagai sarana penguatan karakter siswa yang salah satunya melalui apresiasi cerita rakyat. Dalam kurikulum yang digunakan di Indonesia yang sekarang ini yakni KTSP dan Kurikulum 2013 mengisyaratkan penekanan pada aspek kognitif, afektif, dan psikomotor. Akan tetapi, aspek terpenting dari ketiga itu adalah penekanan terhadap aspek afektif karena sangat membuka ruang guna memperkuat karakter siswa. Pembelajaran sastra yakni mengapresiasi karya sastra dapat dijadikan sarana untuk penguatan karakter bangsa. Oleh karena itu, peran penting dari pemerintah, guru, teks cerita, dan pengarang perlu memperhatikan keberadaan sastra terutama cerita rakyat. Apabila hal tersebut dilaksanakan dengan baik tentu saja akan berdampak pada kesiapan bangsa (masyarakat) Indonesia dalam menghadapi era industri sekarang. Perhelatan dan persaingan bangsa di era revolusi industri 4.0 menjadi tantangan terbesar bagi bangsa Indonesia guna menjadikan bangsa yang majemuk dan sejahtera

\section{DAFTAR PUSTAKA}

Abad, P. G. S. D. (n.d.). PROSIDING.

Aminudddin, M. P., \& Suryana, H. (2000). Pengantar apresiasi karya sastra. PT Sinar Baru Algensindo.

Atmaja, T. S., Dewantara, J. A., \& Utomo, B. B. (2020). Penguatan Pendidikan Karakter Berbasis Sekolah Menengah Atas Perbatasan Entikong Kalimantan Barat. Jurnal Basicedu, $4(4), 1257-1266$. 
326 Apresiasi Cerita Rakyat Sebagai Upaya Memperkuat Karakter Siswa Dalam Menghadapi Revolusi Industri 4.0 - Kuswara, Yena Sumayana

DOI: https://doi.org/10.31004/basicedu.v5i1.678

Balasingham, K. (2016). Industry 4.0: securing the future for German manufacturing companies. University of Twente.

Burhan, N. (2005). Sastra Anak Pengantar Pemahaman Dunia Anak. Yogyakarta: Gadjah Mada Univerity Press. Prasetyo. Journal. Unnes. Ac. Id/Sju/Index. Php/Seloka.

Depdiknas, U.-U. R. I. N., \& No, R. I. (2003). Tahun 2003 tentang sistem pendidikan nasional. Jakarta: Depdiknas.

Dewantara, J. A., Efriani, E., Sulistyarini, S., \& Prasetiyo, W. H. (2020). Optimization of Character Education Through Community Participation Around The School Environment (Case Study in Lab School Junior High School Bandung). JED (Journal of Etika Demokrasi), 5(1), 53-66.

Fadjar, A. M. (2005). Holistika Pemikiran Pendidikan, ed. Ahmad Barizi, Jakarta: PT. Raja Grafindo Persada.

La ode Onde, M., Aswat, H., Fitriani, B., \& Sari, E. R. (2020). Integrasi Penguatan Pendidikan Karakter (PPK) ERA 4.0 Pada Pembelajaran Berbasis Tematik Integratif Di Sekolah Dasar. Jurnal Basicedu, 4(2), 268-279.

Naim, N. (2012). Character building. Jogjakarta: Ar-Ruzz Media.

Nasional, D. P. (2003). Undang-Undang Nomor 20 Tahun 2003 Tentang Sistem Pendidikan Nasional. Jakarta: Depdiknas, 33.

Prasetyo, H., \& Sutopo, W. (2018). Industri 4.0: Telaah Klasifikasi aspek dan arah perkembangan riset.J@Ti Undip: Jurnal Teknik Industri, 13(1), 17-26.

Qin, J., Liu, Y., \& Grosvenor, R. (2016). A categorical framework of manufacturing for industry 4.0 and beyond. Procedia Cirp, 52, 173-178.

Razdan, R., Das, M., \& Sohoni, A. (2013). The evolving Indonesian consumer. Retrived from: Https://Www. Mckinsey.
Com/Business-Functions/Marketing-andSales/Our-Insights/the-Evolving-IndonesianConsumer.

Rianse, U., \& Abdi. (2008). Metodologi penelitian sosial dan ekonomi: teori dan aplikasi. Alfabeta.

Salahudin, A., \& Alkrienciehie, I. (2013). Pendidikan karakter: pendidikan berbasis agama \& budaya bangsa. Pustaka Setia.

Sedyawati, E. (1981). Pertumbuhan Seni Pertunjukkan, Sinar Harapan. Jakarta.

Suwardana, H. (2018). Revolusi Industri 4. 0 Berbasis Revolusi Mental. JATI UNIK: Jurnal Ilmiah Teknik Dan Manajemen Industri, 1(2), 109-118.

Wahyuddin, W. (2016). Kemampuan Menentukan Isi Cerita Rakyat Siswa Kelas X SMA Negeri 1 Raha. Jurnal Bastra, 1(01). 